\title{
Status of Digital Learning Practices in Health Sciences Education in Pakistan
}

\author{
Hussain Maqbool Ahmed Khuwaja ${ }^{1}$ \\ MSc \\ Ali Maqbool ${ }^{2}$ \\ BDS, MSc \\ Komal Abdul Rahim ${ }^{3}$ \\ BScN \\ Sana Gul ${ }^{4}$ \\ BScN \\ Sanam Hanif ${ }^{5}$ \\ BScN \\ Shabnoor Karim ${ }^{6}$ \\ BScN
}

OBJECTIVE: To assess the status of digital learning practices among recognized degree awarding medical, dental and nursing education institutes in Pakistan.

METHODOLOGY: In this descriptive cross-sectional study, all medical, dental and nursing education institutes registered with PMDC and PNC were approached between 1st April and 15th April, 2020. Data was collected on use of online classes during routine academic year as well as during COVID19 Pandemic.

RESULTS: There were 111 medical colleges, 52 dental colleges and 62 nursing education institutes found in latest lists available on PMDC and PNC websites. Majority of health sciences education institutions were found in Punjab and Sindh, indicating sheer discrimination with other provinces of Pakistan. Use of online classes was found very low in routine academic year in all three disciplines of health sciences education explored in this study.

CONCLUSION: HEC, PMDC and PNC must realize the scope of digital learning, and invest in infrastructure and capacity building for digital learning in health sciences education in Pakistan.

KEYWORDS: Online learning, Virtual learning, Online Classes, Medical Education

HOW TO CITE: Khuwaja HMA, Maqbool A, Gul S, Hanif S, Karim S. Status of digital learning practices in health sciences education in Pakistan. J Pak Dent Assoc 2020;29(S):S30-35.

DOI: https://doi.org/10.25301/JPDA.29S.S30

Received: 30 April 2020, Accepted: 16 June 2020

\section{INTRODUCTION}

$\mathrm{H}$ ealth Sciences Education in Pakistan includes many disciplines ranging from medicine, nursing, pharmacy, physiotherapy, healthcare administration, public health to technicians and biomedical technology. The curriculum of all the higher education programs is over seen by Higher Education Commission (HEC). The Higher Education Commission of Pakistan is a self-sufficient, independent and constitutional establishment for directing, managing, authorizing, funding and monitoring the advanced

1. Senior Instructor, School of Nursing and Midwifery at Aga Khan University.

2. Assistant Professor and Vice Principal, Department of Oral Biology and Health Professional Education, , Bhittai Dental and Medical College.

3. Registered Nurse, Aga Khan University Hospital.

4. Registered Nurse, Aga Khan University Hospital

5. Registered Nurse, Aga Khan University Hospital.

6. Registered Nurse, Aga Khan University Hospital

Corresponding author: “Dr. Ali Maqbool” < khuwajas@gmail.com > education endeavors in Pakistan. ${ }^{1}$

Parallel to HEC, other independent regulatory bodies such as Pakistan Medical and Dental Council (PMDC) and Pakistan Nursing Council (PNC) look after undergraduate and post graduate medical and nursing education programs in Pakistan. However, the current healthcare education curriculums and its delivering methodologies have tragically relapsed and have standardized average quality that requires major revamping in content as well instruction. ${ }^{2,3}$ HEC, PMDC, PNC and every single administrative authority need to develop and acknowledge the way that instruction and preparing programs in health sciences in Pakistan need massive change to meet the blossoming healthcare needs and the utilization of modern tools for instance, Artificial Intelligence, Stem Cells Research, Evidence based Medicine, Simulation etc. ${ }^{4}$

The current pedagogical approaches in most of the medical, nursing and dental colleges include instructor 
focused, customary subject based curricula, traditional clinical rotations and class room teaching being overseen by educators with minimal proper training in educating and learning. There is minimum availability of simulation based learning or implementation of virtual learning space in most of the schools. ${ }^{5}$ In the last decade, health sciences education advanced in few private universities which are now offering simulation based and problem based learning. Recently, the World Health Organization (2020), characterized COVID19 as a global pandemic. With the rapid increase in number of cases and no definitive treatment options available for COVID-19, social distancing is considered crucial in reducing the transmission of virus. ${ }^{6}$ Thus, many affected countries around the world have suspended educational institutions as a physical distancing mechanism in order to reduce transmission of COVID-19. ${ }^{7}$ This suspension of educational institutions has severe consequences on education and is affecting around millions of student population worldwide. $^{8}$

Suspending educational institutions, even for the time being can cause hurdles in students learning, performance and skills. It also causes educational inequalities as everybody do not have access to alternative resources like virtual learning management systems to fill the gap. ${ }^{8}$ Significantly many educational institutions around the world have switched to digital mode of learning for continuing education, however, in Pakistan because of low literacy rates and small budget being allocated to education sector and generating only 2.1 percent GDP, makes it extremely difficult for investments in resources to uplift from practicing traditional modes of education to digital modes of learning. ${ }^{9}$ Previous study conducted on exploring challenges of implementing e-learning in a Pakistani university shows that there is less access to digital modes of learning among students in Pakistan. ${ }^{10}$ Therefore, this research, aims to assess the digital learning practices in health sciences education institutes of Pakistan. Furthermore, we discuss different modes of digital learning strategies available for Higher Education Institutes across Pakistan.

\section{METHODOLGY}

This is a descriptive study to collect information from recognized degree awarding health sciences education institutes registered under PMDC and PNC. For the purpose of data collection, lists of recognized health sciences education institutes were used from official websites of PMDC and PNC. Data was collected from the institutes registered with these regulatory bodies until the latest lists were updated and officially available. Data was collected via phone calls on an investigator derived questionnaire (Figure 1) that comprised of questions related to online learning being offered during routine academic year as well as during COVID19 period. This questionnaire was developed on the basis of rapid assessment method as a tool to explore the current online learning practices, hence, it is not a validated questionnaire but a rational approach to conduct rapid needs assessment.

Figure 1: Study Questionnaire

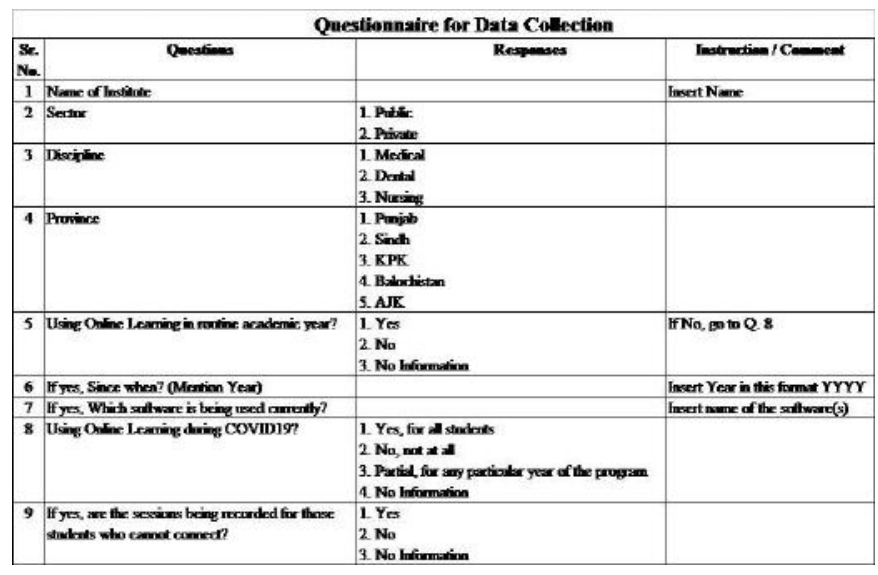

We collected data from 1st April to 15th April, 2020, and entered it in Google Forms. Official websites and social media accounts were also screened for the academic institutes to broaden the data collection strategy where phone numbers were either not available or not being answered due to academic closure. In the absence of any formal list available for contact numbers of all Deans and HODs of all health sciences education institutions, contact numbers of faculty members teaching in various academic institutes were collected via snowball approach because majority of the teaching institutes were closed during COVID19 phase. Snowball approach or network approach was utilized to contact full-time faculty members of respective institutions (11). Descriptive data analysis was done to assess the status of online learning in medical, dental and nursing education institutes. Ethical Review was obtained from Bhitai Dental and Medical College, Department of Research and Development [ERC No. BDMC/R\&D/ERC/2020-05].

\section{RESULTS}

The number of medical and dental colleges recognized by PMDC are 114 and 55 respectively. However, 3 medical colleges and 3 dental colleges have been asked to stop admission by PMDC, resulting in 111 medical colleges and 52 dental colleges. There are 62 recognized degree awarding nursing schools mentioned in the latest list available on PNC website. Table 1 clearly shows the disparity in health sciences 
education institutes in Pakistan where majority of the recognized institutes are located in Punjab and Sindh.

Table 1: Distribution of Recognized Health Science Education Institutes across Pakistan

\begin{tabular}{|l|c|c|c|c|c|c|c|c|c|}
\hline \multirow{2}{*}{ Location } & \multicolumn{3}{|c|}{ Medical Colleges } & \multicolumn{3}{c|}{ Dental Colleges } & \multicolumn{3}{c|}{ Nursing Institutes } \\
\hline & Public & Private & Total & Public & Private & Total & Public & Private & Total \\
\hline Punjab & 19 & 42 & 61 & 4 & 22 & 26 & 4 & 19 & 23 \\
\hline Sindh & 11 & 13 & 24 & 6 & 10 & 16 & 7 & 21 & 28 \\
\hline KPK & 10 & 10 & 20 & 4 & 5 & 9 & 3 & 5 & 8 \\
\hline Balochistan & 1 & 1 & 2 & 1 & 0 & 1 & 1 & 2 & 3 \\
\hline AJK & 3 & 1 & 4 & 0 & 0 & 0 & 0 & 0 & 0 \\
\hline Total & 44 & 67 & 111 & 15 & 37 & 52 & 15 & 47 & 62 \\
\hline
\end{tabular}

Table 2 shows the number of higher education institutes which are practicing online learning during routine academic year as compared to online learning being offered during COVID19 pandemic. Out of 111 medical colleges, merely 24 colleges $(19.5 \%)$ offer online learning during academic year and 25 (22.5\%) are offering during COVID19. Among 52 dental colleges, only 9 colleges $(17.3 \%)$ offer online learning during routine academic year, whereas, 14 colleges (26.9\%) are offering online learning during COVID19. Out of 62 recognized degree awarding nursing institutes, only 3 institutes $(4.8 \%)$ offer online learning during routine academic year, whereas, 19 institutes $(30.6 \%)$ are offering it during COVID19. It is evident that the percentage of higher education institutes that offer online learning during routine academic year is extremely low.

Table 2: Online Learning (OL) in Recognized Health Science Education Institutes across Pakistan

\begin{tabular}{|c|c|c|c|c|c|c|c|c|c|c|c|c|}
\hline \multirow{3}{*}{ Location } & \multicolumn{4}{|c|}{ Medical Colleges } & \multicolumn{4}{|c|}{ Dental Colleges } & \multicolumn{4}{|c|}{ Nursing Institutes } \\
\hline & \multicolumn{2}{|c|}{$\begin{array}{c}\text { OL during } \\
\text { routine } \\
\text { Academic Year }\end{array}$} & \multicolumn{2}{|c|}{$\begin{array}{l}\text { OL. during } \\
\text { COVID19 }\end{array}$} & \multicolumn{2}{|c|}{$\begin{array}{c}\text { OL during } \\
\text { routine } \\
\text { Academic Year }\end{array}$} & \multicolumn{2}{|c|}{$\begin{array}{l}\text { OL during } \\
\text { Covid19 }\end{array}$} & \multicolumn{2}{|c|}{$\begin{array}{c}\text { OL during } \\
\text { routine } \\
\text { Academic Year }\end{array}$} & \multicolumn{2}{|c|}{$\begin{array}{l}\text { OL during } \\
\text { Covid19 }\end{array}$} \\
\hline & Public & \begin{tabular}{|l|} 
Private \\
\end{tabular} & $\begin{array}{l}\text { Public } \\
\end{array}$ & Private & Public & $\begin{array}{l}\text { Private } \\
\end{array}$ & Public & Private & Public & \begin{tabular}{|l|} 
Private \\
\end{tabular} & Publie & Private \\
\hline Punjab & 5 & 8 & 5 & 7 & 1 & 2 & 1 & 4 & 0 & 1 & 4 & 4 \\
\hline Sindh & 4 & 4 & 4 & 5 & 3 & 2 & 3 & 5 & 0 & 2 & 2 & 5 \\
\hline KPK & 1 & 1 & 1 & 2 & 0 & 1 & 0 & 1 & 0 & 0 & 0 & 4 \\
\hline \begin{tabular}{|l|} 
Balochistan \\
\end{tabular} & 0 & 0 & 0 & 0 & 0 & & 0 & & 0 & 0 & 0 & 0 \\
\hline AJK & 1 & 0 & 1 & 0 & & & & & & & & \\
\hline Total & 11 & 13 & 11 & 14 & 4 & 5 & 4 & 10 & 0 & 3 & 6 & 13 \\
\hline
\end{tabular}

\section{DISCUSSION}

Due to rapid the spread of COVID 19, academic halt foisted many health sciences universities to digitalize the learning environment; so students will get an opportunity to be fairly interactive with substantive online resources in the absence of traditional classroom setup. The accessibility, affordability and availability of accessories for distance learning have always been challenging for developing countries. Nonetheless, out of eight countries in South Asian
Association for Regional Cooperation (SAARC) i.e. Bangladesh, India, Pakistan, Sri Lanka and Afghanistan somehow manage to create e-learning platforms for their students. ${ }^{12}$ Various studies have shown India is growing up in providing e-learning in medical education. Online Google groups are being used extensively by Medical Council of India to train medical faculty, user friendly app on smartphones allow medical students to participate in videoconferencing. ${ }^{13}$ Currently, synchronous learning has almost been ubiquitous all around the world; where educator, trainer, consultant and medical staff are connecting with student, trainee, consultee and patient respectively in their real time. A study described that video conferencing is considered a remarkable synchronous approach for medical and nursing students of Sub Saharan Africa. ${ }^{14}$ Blended learning approach via a Learning Management System (LMS) is also being implemented in few nursing, medical and dental universities in Pakistan ${ }^{15-17}$ for instance in DOW University of Health Sciences ${ }^{15,18}$ and the Aga Khan University. ${ }^{19}$ Synchronous and asynchronous video/audio, Virtual Learning Environment (VLE), videoconferences, online discussion forums, Virtual Classroom, Repository and Hypertext are some of the common digital modalities used in Pakistan's medical universities. ${ }^{9}$ Although 1 in 4 health sciences education institutions in Pakistan are offering online learning according to our data, many universities are still deprived with accessibility of technical and spacious setup, availability of internet facilities/ electronic gadgets at home and adequate funds; which are creating barriers in implementation of e-learning. ${ }^{20}$

As the need for e-learning is increasing in health sector for continuous medical and nursing education, it is also important for non-health sciences institutions to engage themselves in digital learning. According to the HEC Universities ranking ${ }^{21}$, National University of Sciences and Technology (NUST) being the top most in engineering field is using blended learning in their curricula. National College of Arts (NCA) being top amongst the Arts universities is also using online classes as a mode of delivering classes during COVID-19 outbreak. In addition to these, Institute of Business Administration (IBA), and SZABIST are also playing their part to promote blended learning in their academic years and during COVID-19 pandemic. According to HEC's recent guidelines, Higher Education Institutions (HEIs) in Pakistan can use different technology solutions especially during this pandemic outbreak, so that the education of students does not suffer. These guidelines have detailed instructions for HEIs to prepare faculty members for online readiness and faculty's capacity in conducting online classes. ${ }^{22}$ Some of these software's are Modular ObjectOriented Dynamic Learning Environment (MOODLE), 
Google Classrooms, Microsoft Teams, and Virtual University Learning Management System (LMS). There are also forums for video conferencing such as Zoom, Adobe Connect, WebEx, and BigBlueButton. ${ }^{23}$

Diversified approaches of digital learning during the corona pandemic crisis may significantly deliver tremendous benefits to higher education system. On the contrary, biomedical community i.e. students, educators and institutions are left in uncharted water to cross over the barriers in initiating the distance education platforms.

Digital learning in health sciences has incredibly impressed technology user-friendly students. It has also given an opportunity to students to easily access in their flexible time, place and as frequently reuse the e-resources as well. Synchronous online forums are also beneficial to promote networking among peer to peer or student to faculty communication via instant messages, live videos, interactive white boards and sharing resources in real time. ${ }^{24}$ However, few students criticized synchronous mode as a missing opportunity to build teacher student relationship. ${ }^{25} \mathrm{~A}$ study suggested that Massive Open Online Courses (MOOC) like "Discover Dentistry"26 could motivate students to enthusiastically participate in the flipped classroom. ${ }^{27} \mathrm{On}$ the contrary, unavailability of digital gadgets i.e. laptops, smartphones, computers etc. affect the computer literacy among few medical and dental students of developing countries ${ }^{15,28}$ which demotivates the students towards digital environment. Hence, adequate equipment and vocational facilitation is needed before a successful implementation of digital learning is expected.

Globally, health sciences faculty members highly appreciate the e-learning environment in terms of time effectiveness in upgrading the resources and it allows them to learn and reflect upon various concepts according to evidence based practices in medical education. ${ }^{27,29}$ Similarly, few educators shared their positive reviews regarding Virtual Classroom; it provides platform to students for easily accessing PowerPoint presentation, recoded lectures, and step by step instructions to attempt quizzes and get feedback on it . ${ }^{25}$ On the other hand, lack of technical skills i.e. inability to operate software to create online discussion forum, selection of software to interact with students through videoconference, recording lectures and typing skills elevate resilience for faculty to adopt digital learning environment. ${ }^{28}$

HEC's online learning guidelines for HEIs suggest that they need to be very clear in terms of effective utilization of material, human and financial resources within their constraints for the integration of e-resources in offering online classes. ${ }^{22,30}$ It gives economical advantage to the institution by giving coverage to large volume of users in long run. One study from Pakistan suggested that webinars or online lectures are the simplest and user friendly modalities to initiate routine academic activities such as those sessions which do not require a practical training such as small classroom discussions or large classroom lectures. ${ }^{17}$ While, to ensure the faculty and student have adequate internet connectivity, accessories of digital gadgets at home, maintaining quality of e-learning are the most crucial and serious concerns for all the universities in Pakistan; if these concerns are not addressed, they may lead to cancellation of the semester by the universities.$^{30}$ At the same time, professional training and strengthening the confidence in faculty, students and IT professionals at the institutional level must be a major challenge in implementation of e-learning. ${ }^{28}$

To the best of our knowledge, this is the first attempt to map the status of online learning in medical, dental and nursing schools of Pakistan. No previous study has conducted such assessment. We acknowledge the fact that there may be some data which we would have missed due to unavailability of information. However, there is clear evidence in itself that all academic institutions in this digital era must have their websites updated and official social media pages available for current as well as prospective students to approach them virtually. ${ }^{31}$

\section{CONCLUSION}

This study draws attention to a dire need of investment in capacity building of educators as well as development of necessary infrastructure in health sciences education institutions in Pakistan. Due to COVID19 Pandemic, many things will leave an everlasting impact on the lives of people. Thus, PMDC and PNC must realize the need for digital learning, especially online classes to support health sciences education as an effective strategy as per HEC's evidence based guidelines. Furthermore, research on the efficacy of online teaching, readiness of educators, satisfaction of students and feasibility of scaling up digital learning in post-graduate health sciences education programs need to be conducted.

\section{ACKNOWLEDGEMENT}

None

\section{FUNDING DISCLOSURE}

None

\section{DISCLOSURE STATEMENT}

All authors declare that they have no conflicts of interest 
in regard to this work.

\section{CONFLICT OF INTEREST}

None declared

\section{REFERENCES}

1. Khan TA, Jabeen N. Higher Education Reforms and Tenure Track in Pakistan: Perspectives of Leadership of Regulatory Agencies. Bull Educ Res. 2019;41:181-205.

2. Nasim M. Medical education needs to change in Pakistan. JPMAJ Pak Med Assoc. 2011;61:808.

3. Khan AW, Sethi A, Wajid G, Yasmeen R. Challenges towards quality assurance of Basic Medical Education in Pakistan. Pak J Med Sci. 2020;36:4-9.

https://doi.org/10.12669/pjms.36.2.1319

4. Memon AR, Rathore FA. Moodle and Online Learning in Pakistani Medical Universities: An opportunity worth exploring in higher education and research. J Pak Med Assoc. 2018;68:1076-78.

5. Latif MZ, Wajid G. Reforming Medical Education in Pakistan through strengthening Departments of Medical Education. Pak J Med Sci. 2018;34:1439.

https://doi.org/10.12669/pjms.346.15942

6. Anderson RM, Heesterbeek H, Klinkenberg D, Hollingsworth TD. How will country-based mitigation measures influence the course of the COVID-19 epidemic? The Lancet. 2020;395(10228):931-34. https://doi.org/10.1016/S0140-6736(20)30567-5

7. Rose S. Medical Student Education in the Time of COVID-19. J Am Med Assoc.2020.

https://doi.org/10.1001/jama.2020.5227

8. UNESCO. COVID-19 Educational Disruption and Response: United Nations Educational, Scientific and Cultural Organization; 2020 [Available from: https://en.unesco.org/covid19/educationresponse.

9. Adnan M, Yousaf Z, Gilani AH. E-Learning with Digital Media and Human Development: The Way Forward for Pakistan. J Educ Res. (1027-9776). 2019;22(2).

10. Qureshi IA, Ilyas K, Yasmin R, Whitty M. Challenges of implementing e-learning in a Pakistani university. Knowledge Management \& E-Learning: An Int J. 2012;4:310-24.

https://doi.org/10.34105/j.kmel.2012.04.025

11. Sadler GR, Lee HC, Lim RSH, Fullerton J. Recruitment of hardto-reach population subgroups via adaptations of the snowball sampling strategy. Nurs Health Sci. 2010;12:369-74.

https://doi.org/10.1111/j.1442-2018.2010.00541.x

12. Hazra UK, Das R, Mukherjee S. e-Learning Platform in SAARC Countries. Library Philosophy and Practice. 2019:1-9.
13. Dhir SK, Verma D, Batta M, Mishra D. E-learning in medical education in India. Indian Pediatrics. 2017;54:871-77.

https://doi.org/10.1007/s13312-017-1152-9

14. Mars M. Building the capacity to build capacity in e-health in sub-Saharan Africa: the KwaZulu-Natal experience. Telemed e-Health. 2012;18:32-7.

https://doi.org/10.1089/tmj.2011.0146

15. Baig QA, Zaidi SJA, Alam BF. Perceptions of dental faculty and students of E-learning and its application in a public sector Dental College in Karachi, Pakistan. J Pak Med Assoc. 2019;69, No.9:1319324

16. Cassum S, Hussein S, Allana S, Dias JM. Experiences of adopting blended pedagogies in health assessment course in post RN baccalaureate program of nursing in Karachi, Pakistan. J Educ Training Studies. 2016;4:221.

https://doi.org/10.11114/jets.v4i1.1168

17. Jawaid M, Aly SM. 'E-learning'modalities in the current era of Medical Education in Pakistan. Pakistan J Medi Sci. 2014;30:1156. https://doi.org/10.12669/pjms.305.4351

18. Jawaid M, Ashraf J. Initial experience of eLearning research module in undergraduate medical curriculum of Dow University of Health Sciences: Development and students perceptions. Pakistan J Medi Sci. 2012;28.

19. Dias JM, Kurji Z. Evaluation of teaching and learning course in the nursing baccalaureate curriculum in one University Teaching Hospital in Karachi, Pakistan. Procedia-Soc Behavior Sci. 2011;15:29636

https://doi.org/10.1016/j.sbspro.2011.04.223

20. Ali S, Uppal MA, Gulliver SR. A conceptual framework highlighting e-learning implementation barriers. Information Technology \& People. 2018.

https://doi.org/10.1108/ITP-10-2016-0246

21. HEC. 5th Ranking of Pakistani Higher Education Institutions (HEIs). Higher Education Commission; 2016.

22. HEC. HEC COVID-19 GUIDANCE 2020 [Available from: https://www.hec.gov.pk/english/Pages/Covid-19-Guidance.aspx.

23. Khan AS, Ghani ST, Naeem, Qayyum Z, Rashid R. How can Universities prepare for the transition to virtual instruction? : Higher Education Commission; 2020.

24. King S, Greidanus E, Carbonaro M, Drummond J, Boechler P, Kahlke R. Synchronous Problem-Based e-Learning (ePBL) in Interprofessional Health Science Education. J Interactive Online Learn. 2010;9:133-50

25. Masic I. E-learning as new method of medical education. Acta informatica medica. 2008;16:102.

https://doi.org/10.5455/aim.2008.16.102-117

26. Stokes C, Towers A, Jinks P, Symington A. Discover Dentistry: 
encouraging wider participation in dentistry using a massive open online course (MOOC). Bri Dent J. 2015;219:81-5.

https://doi.org/10.1038/sj.bdj.2015.559

27. O'Doherty D, Dromey M, Lougheed J, Hannigan A, Last J, McGrath D. Barriers and solutions to online learning in medical education-an integrative review. BMC Med Educ. 2018;18:130.

https://doi.org/10.1186/s12909-018-1240-0

28. Ranasinghe P, Wickramasinghe SA, Pieris WR, Karunathilake I, Constantine GR. Computer literacy among first year medical students in a developing country: A cross sectional study. BMC Res Notes. 2012;5:504.

https://doi.org/10.1186/1756-0500-5-504
29. Huynh R. The role of E-learning in medical education. Academic Medicine. 2017;92:430.

https://doi.org/10.1097/ACM.0000000000001596

30. HEC. Government Directive of 26 March 2020. In: Commission HE, editor. 2020.

31. Bélanger $\mathrm{CH}$, Bali S, Longden B. How Canadian universities use social media to brand themselves. Tertiary Educ Manage. 2014;20:1429.

https://doi.org/10.1080/13583883.2013.852237 